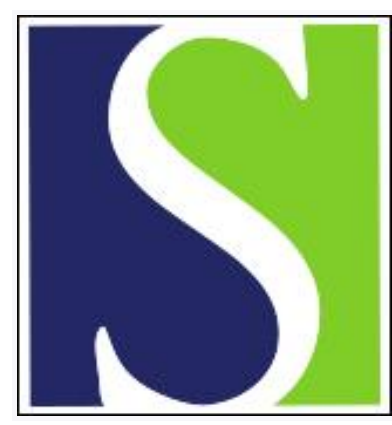

Scand J Work Environ Health 1994;20(3):206-212

https://doi.org/10.5271/sjweh.1407

Issue date: 01 Jun 1994

\section{Prevalence of hand dermatoses among Finnish farmers.}

by Susitaival P, Husman L, Horsmanheimo M, Notkola V, Husman K

Affiliation: Kuopio Regional Institute of Occupational Health, Finland.

This article in PubMed: www.ncbi.nlm.nih.gov/pubmed/7973493 


\title{
Prevalence of hand dermatoses among Finnish farmers
}

\author{
by Päivikki Susitaival, MD, ${ }^{1}$ Liisa Husman†, MD, ${ }^{2}$ Maija Horsmanheimo, MD, ${ }^{2}$ \\ Veijo Notkola, PhD, ${ }^{1}$ Kaj Husman, MD'
}

\begin{abstract}
SUSITAIVAL P, HUSMAN L, HORSMANHEIMO M, NOTKOLA V, HUSMAN K. Prevalence of hand dermatoses among Finnish farmers. Scand $J$ Work Environ Health 1994;20:206-12.
\end{abstract}

\begin{abstract}
Orjectives - The goal of this study was to determine the prevalence and risk factors of hand dermatosis among farmers.

Methods - A questionnaire survey was carried out in a geographically defined sample of the Finnish farming population between the ages of 18 and 64 years $(N=10847)$.

RESULTS - The one-year prevalence of self-reported hand and forearm dermatoses was $16 \%$ for the women and $7 \%$ for the men. These figures were similar to the prevalence of hand eczema in two large Scandinavian questionnaire surveys. The highest one-year prevalence of hand dermatoses was found for women on farms with more than nine dairy cows $(20 \%)$. Atopy (both the personal history of atopic dermatitis and respiratory atopy), female gender, and, among the women, also age under 35 years were the most important risk factors for the occurrence of hand dermatosis. Work-related risk factors were handling disinfectants daily, handling silage preservatives, milking cows, and machine servicing.

Conclusions - Occupational risk factors for hand dermatoses were found, especially for dairy farming. The results may be useful for the prevention of hand dermatoses in farming since they direct attention to related occupational hazards, and they may also aid vocational guidance for the atopic population. In order to lower the prevalence of hand dermatoses in dairy farming, both preventive and protective measures should become everyday practice in farming work.
\end{abstract}

KEY TERMS - agriculture, atopy, epidemiology, questionnaire study, work-related.

According to the United States Bureau of Labour Statistics, from 1973 to 1984 , the highest incidence rates of occupational skin diseases were recorded for agriculture (1). In the same statistics two-thirds of all occupational illnesses within agriculture were skin diseases. In Finland, farmers have been compensated for occupational diseases since 1982. Since then, the incidence of occupational skin diseases registered for farmers in the Finnish Register of Occupational Diseases has reached the level of top industries and was 1.7 cases per 1000 active farmers or farm workers in 1992 (2). Farm work comprises a variety of jobs according to the operation of the farm. Many of these jobs are hazardous to the skin, especially the skin of hands and forearms. Frequent skin contact with moisture, chemicals, friction, or dirt has been connected with a higher risk of hand eczema in several studies (3-5). Agricultural work, especially dairy farming, includes all these elements daily. Epidemiologic data concerning skin diseases in the farming industry are very scarce.

Kuopio Regional Institute of Occupational Health, Kuopio, Finland.

2. Department of Dermatology, University of Kuopio, Kuopio, Finland.

Reprint requests to: Dr P Susitaival, Kuopio Regional Institute of Occupational Health, PO Box 93, FIN-70701 Kuopio, Finland.
The aims of this study were to determine the occurrence of hand dermatoses among Finnish farmers and to establish which risk factors are constitutional (gender, atopy) and which are work-related.

\section{Subjects and methods}

In November 1979 a questionnaire was sent to all of the 14346 registered 18- to 64-year-old farmers in 14 Finnish municipalities. The sample was $5 \%$ of all farmers in Finland, and it represented the geographic, social, gender, and age distributions and the different farm operations of the total farming population (6). The questionnaire was self-administered and contained personal questions on health and work.

A total of 13054 farmers filled out and returned the questionnaire $(91 \%)$. Of these, 10847 were professional farmers, who constituted the population of this study. The mean ages in the study population were 44.7 years for the men $(\mathrm{N}=5581)$ and 46.1 years for the women $(\mathrm{N}=5266)$. Thirty percent of the men and $26 \%$ of the women were under 40 years of age. The study included 6796 farms. The mean area of cultivated land was $\mathbf{1 3 . 2}$ ha per farm. On most farms, a married couple (family) or a single farmer did all of the work without hired workers. On 4484 farms $(66 \%)$ with 7508 farmers $(69 \%)$ there was at least one dairy cow. The mean number of dairy cows was 7.5 per farm. On $6 \%$ of the farms the main farm 
operation was swine breeding, on $4 \%$ it was other animal breeding, mostly beef cattle, and on $14 \%$ it was raising crops, other plant cultivation or forestry. On the farms with dairy cattle, $86.3 \%$ of the women and $56.2 \%$ of the men milked cows regularly. Milking was still done by hand on $51 \%$ of the farms with one to five cows in 1979.

In the questionnaire, the first two questions concerning the skin were "Do you have a skin disease now?" and "Have you had any skin disease within the last year?" The positive answers to the first question gave the point prevalence, and positive answers to either of the questions provided the oneyear prevalence of skin diseases. The persons who answered "yes" to either of the two questions were asked to shade the areas of their eczema on a picture (figure 1). The hand and forearm were together in the same area. Data on skin disease areas were missing for $5.9 \%$ of the men and $5.6 \%$ of the women. The questions about atopic background were "Do you have or have you had infantile eczema or eczema on antecubital fossae or knee flexures?" and "Do you have or have you had seasonal or other allergic rhinitis or bronchial asthma?" Farmers with a positive answer to the first question formed the "atopic dermatitis" group, which also included people with respiratory symptoms. Farmers with a positive answer to the second question alone were included in the "atopic respiratory disease" group. The two groups were included in the atopics, and the rest of the subjects were considered nonatopic. A history of atopic dermatitis was reported by $9.8 \%$ of the men and $10.2 \%$ of the women, and the percentage of farmers with a history of allergic rhinitis or asthma was $22.3 \%$ for the men (18.7\% atopic respiratory disease alone) and $23.9 \%$ for the women (19.9\% atopic respiratory disease alone). Some atopic symptoms were reported by $29.3 \%$ of the farmers.

Gender, age, and family size (all people living in the household) were analyzed from the demographic factors. The covariates from the work were selected with the following three criteria: (i) the type of work (dairy cattle, swine breeding, other animal breeding, plant cultivation), (ii) everyday jobs known to be hazardous to skin (milking, handling disinfectants, handling silage preservatives, machine service work), and (iii) the total work load (the area of cultivated land and the number of dairy cows). All subjects with at least one dairy cow were in the dairy farmer group.

In the statistical analysis of the data, cross-tabulation with the chi-square test, both for heterogeneity and trend, and the multivariate logistic linear regression model were used. Farm operation and number of dairy cows were used separately in the logistic regression model because they measured partly the same parameters (cattle). Farmers with missing data on dermatoses were included in the group with no self-reported dermatoses. The logis-
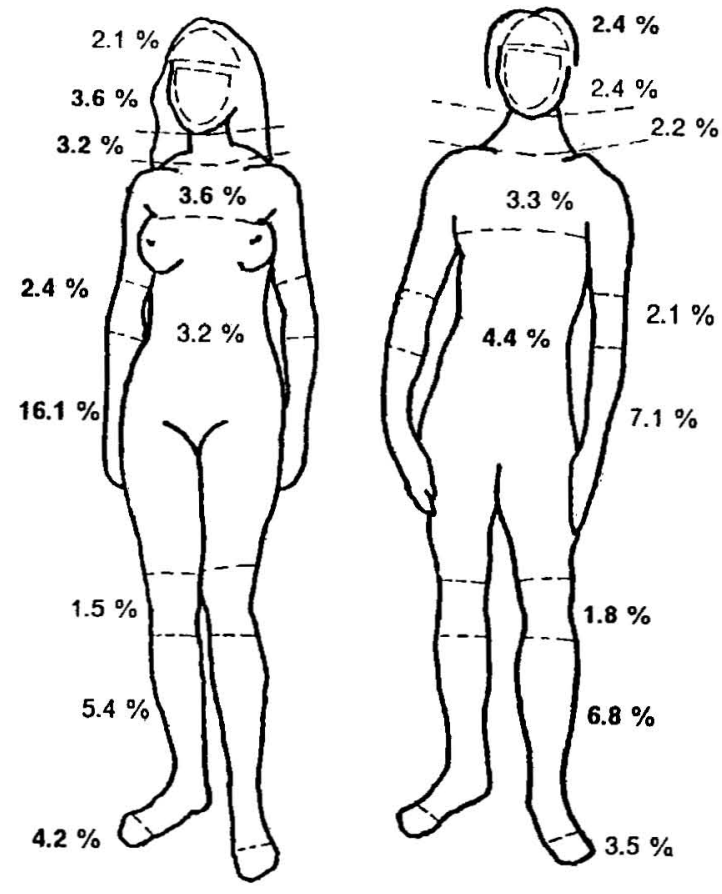

Figure 1. One-year prevalence (\%) of self-reported skin diseases on different skin areas among 5581 male and 5266 female farmers.

tic regression and the calculation of risk ratios were performed by general linear interactive modeling (7).

\section{Results}

\section{All dermatoses}

The point prevalence (present dermatosis) of all reported dermatoses was $16.2 \%$ for the men and $19.8 \%$ for the women. The one-year prevalence of all dermatoses was $23.4 \%$ for the men and $29.4 \%$ for the women (figure 2). The skin disease had persisted for at least one year prior to the inquiry for $42 \%$ of the men and $48 \%$ of the women with dermatoses.

In the atopic dermatitis group, the one-year prevalence of all recent or present dermatoses was more than twice of that in the nonatopic group, and the prevalence was also higher in the atopic respiratory disease group than in the nonatopic group $(\mathrm{P}<0.001)$ (figure 2). The number of atopics among the farmers with dermatoses was $41 \%$ for the men $(20.4 \%$ with atopic dermatitis and $20.4 \%$ with atopic respiratory disease) and $44 \%$ for the women (19.3\% with atopic dermatitis and $25.1 \%$ with atopic respiratory disease).

The hands and forearms were the most frequent sites of reported dermatoses among both genders. The second highest prevalences were reported for the leg. The female farmers reported dermatoses on their hands or forearms $(P<0.001)$ and face $(P<0.001)$ more often than the male farmers, who reported der- 


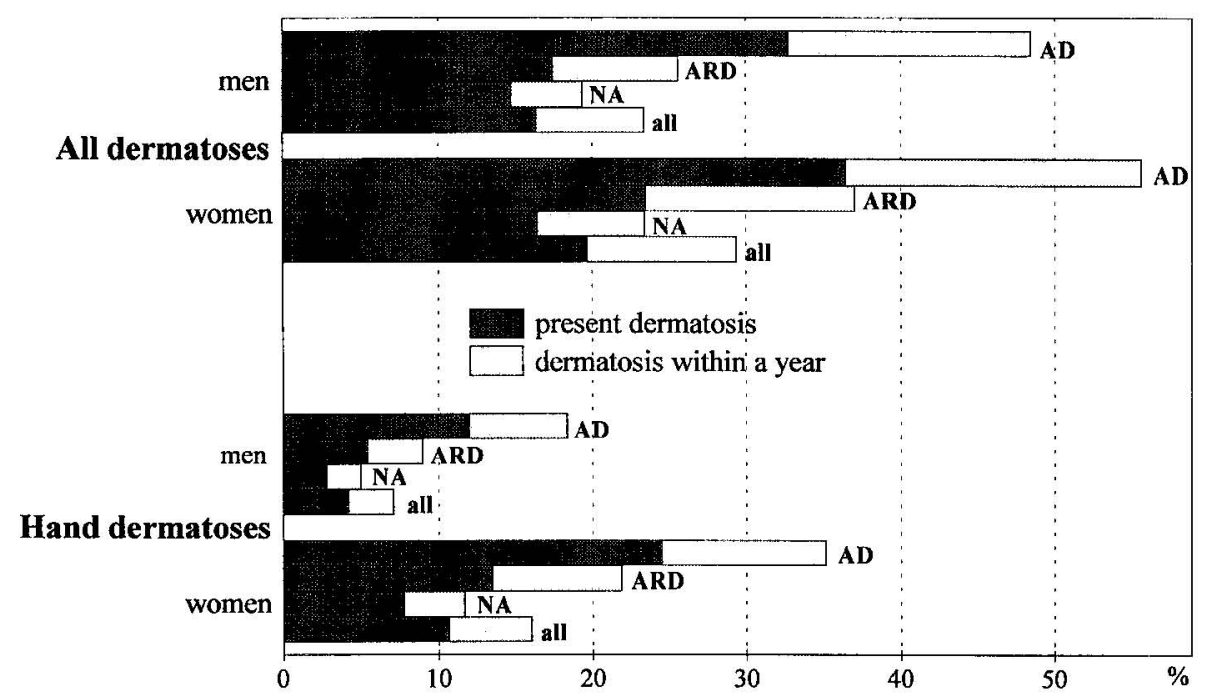

Figure 2. Prevalence of self-reported skin diseases (\%) among 5581 male and 5266 female farmers, by personal history of atopy $(A D=$ history of atopic dermatitis, $A R D=$ history of respiratory atopy without the history of atopic dermatitis, NA $=$ no atopy).

matoses on their trunk $(\mathrm{P}<0.01)$ and legs $(\mathrm{P}<0.01)$ more often than the female farmers (figure 1 ).

\section{Hand and forearm dermatoses}

The women reported hand dermatoses more often than the men $(P<0.001)$. The point prevalence of all hand (and forearm) dermatoses was $10.7 \%$ for the women and $4.2 \%$ for the men, and the one-year prevalence was 16.1 and $7.1 \%$, respectively (figure 2). Within the past year, $10 \%$ of the women and $3.0 \%$ of the men had dermatoses involving only their hands. Only one-year prevalence figures have been reported hereafter, unless otherwise stated. Thirty percent of the men and $55 \%$ of the women who reported dermatoses stated that it occurred on their hands. The percentage of atopics with hand dermatoses was $49 \%$ for both genders. The prevalence of hand dermatoses varied greatly (between 5.0 and $35.2 \%$ ) in relation to gender and atopy (figure 2). For this reason, the study population was divided into groups according to gender and atopy status in the cross-tabulations.

\section{No atopy groups}

Male farmers. The prevalence of hand dermatoses decreased by age among the male farmers $(\mathrm{P}<0.05$, $\chi^{2}$ for trend). (For the classification of age, see table 2.) The number of dairy cows showed a positive correlation with the prevalence of hand dermatoses, as did regular milking also (table 1). Half of the nonatopic men handled silage preservatives, and half of them did machine service work. Both types of work correlated positively with the prevalence of hand dermatoses (table 1).
Female farmers. The prevalence of hand dermatoses decreased also among the female farmers after the age of 34 years $\left(P<0.001, \chi^{2}\right.$ for trend). The female farmers working on farms with dairy cattle had hand dermatoses more often than the women on other farms (table 1). The number of dairy cows and the area of cultivation showed a positive correlation with the prevalence of hand dermatoses (table 1). A positive correlation was also seen between hand dermatoses and regular milking (table 1 ). The women with more than three family members had more hand dermatoses than those with smaller families $(P<0.001$, $\chi^{2}$ for trend). Forty-nine percent of the nonatopic female farmers handled disinfectants daily, and they had more hand dermatoses than those handling disinfectants less often or not at all (table 1). The daily handling of disinfectants correlated also with increasing numbers of cows and family members. Of the nonatopic women $35 \%$ handled silage preservatives; this activity also correlated positively with the prevalence of hand dermatoses in this group (table 1).

\section{Atopy groups}

Male farmers. Male farmers with atopic respiratory disease had hand dermatoses in swine breeding significantly more often than farmers in other operations (table 1). The number of dairy cows and the area of cultivation correlated also positively with the prevalence of hand dermatoses among the male farmers with atopic respiratory disease.

Female farmers. The prevalence of hand dermatoses decreased by age among female farmers with atopic respiratory disease ( $P<0.05, \chi^{2}$ for trend). Hand der- 
Table 1. One-year prevalence (\%) of self-reported hand dermatoses among the male and female farmers in relation to type of farming work. (NS = not significant)

\begin{tabular}{|c|c|c|c|c|c|c|c|c|c|c|}
\hline & \multirow{3}{*}{$\begin{array}{c}\text { Men } \\
(N)\end{array}$} & \multirow{3}{*}{$\begin{array}{l}\text { Women } \\
\text { (N) }\end{array}$} & \multicolumn{8}{|c|}{ History of personal atopy } \\
\hline & & & \multicolumn{2}{|c|}{$\begin{array}{l}\text { No } \\
\text { atopy }\end{array}$} & \multicolumn{2}{|c|}{$\begin{array}{l}\text { Respiratory } \\
\text { atopy }\end{array}$} & \multicolumn{2}{|c|}{$\begin{array}{l}\text { Atopic } \\
\text { dermatitis }\end{array}$} & \multicolumn{2}{|c|}{ All } \\
\hline & & & $\begin{array}{l}\text { Men } \\
(\mathrm{N}= \\
3990)\end{array}$ & $\begin{array}{c}\text { Women } \\
(N= \\
3680)\end{array}$ & $\begin{array}{l}\text { Men } \\
(N= \\
1042)\end{array}$ & $\begin{array}{c}\text { Women } \\
(N= \\
1049)\end{array}$ & $\begin{array}{l}\text { Men } \\
(N= \\
549)\end{array}$ & $\begin{array}{c}\text { Women } \\
(\mathrm{N}= \\
537)\end{array}$ & $\begin{array}{l}\text { Men } \\
(N= \\
5581)\end{array}$ & $\begin{array}{c}\text { Women } \\
(\mathrm{N}= \\
5266)\end{array}$ \\
\hline \multicolumn{11}{|l|}{ Farm operation } \\
\hline $\begin{array}{l}\text { Dairy cattle } \\
\text { Swine breeding } \\
\text { Other animal breeding } \\
\text { Plant cultivation }\end{array}$ & $\begin{array}{r}3730 \\
281 \\
451 \\
860\end{array}$ & $\begin{array}{r}3778 \\
240 \\
393 \\
577\end{array}$ & $\begin{array}{l}5.2 \\
4.9 \\
3.4 \\
4.3\end{array}$ & $\begin{array}{l}13 \\
11 \\
8.7 \\
7.2\end{array}$ & $\begin{array}{c}10 \\
16 \\
5.6 \\
6.5\end{array}$ & $\begin{array}{l}23 \\
7.7 \\
26 \\
20\end{array}$ & $\begin{array}{l}18 \\
24 \\
11 \\
23\end{array}$ & $\begin{array}{l}37 \\
31 \\
34 \\
27\end{array}$ & $\begin{array}{l}7.4 \\
8.9 \\
4.4 \\
6.6\end{array}$ & $\begin{array}{l}17.7 \\
12.9 \\
15.3 \\
11.1\end{array}$ \\
\hline $\mathrm{P}$ for heterogeneity & & & NS & $P<0.001$ & $P=0.042$ & NS & NS & NS & NS & $P<0.001$ \\
\hline \multicolumn{11}{|l|}{ Area of cultivation } \\
\hline $\begin{array}{l}\text { No cultivation } \\
<5 \text { ha } \\
5-10 \text { ha } \\
10-20 \text { ha } \\
>20 \text { ha }\end{array}$ & $\begin{array}{r}187 \\
707 \\
1771 \\
1771 \\
1145\end{array}$ & $\begin{array}{r}216 \\
816 \\
1741 \\
1546 \\
947\end{array}$ & $\begin{array}{l}6.3 \\
3.6 \\
4.8 \\
5.2 \\
5.8\end{array}$ & $\begin{array}{l}4.9 \\
8.8 \\
12 \\
14 \\
12\end{array}$ & $\begin{array}{c}0.0 \\
5.2 \\
7.4 \\
9.9 \\
14\end{array}$ & $\begin{array}{l}26 \\
22 \\
20 \\
24 \\
20\end{array}$ & $\begin{array}{l}6.3 \\
14 \\
22 \\
14 \\
24\end{array}$ & $\begin{array}{l}33 \\
34 \\
32 \\
41 \\
32\end{array}$ & $\begin{array}{l}5.4 \\
5.0 \\
7.0 \\
6.8 \\
9.3\end{array}$ & $\begin{array}{l}10.7 \\
14.0 \\
15.7 \\
19.0 \\
15.2\end{array}$ \\
\hline$P$ for trend & & & NS & $P=0.002$ & $P<0.001$ & NS & NS & NS & $P=0.001$ & $P=0.002$ \\
\hline \multicolumn{11}{|l|}{ Milking work } \\
\hline $\begin{array}{l}\text { No or sometimes } \\
\text { Yes often }\end{array}$ & $\begin{array}{l}3549 \\
2032\end{array}$ & $\begin{array}{l}2002 \\
3264\end{array}$ & $\begin{array}{l}4.1 \\
6.7\end{array}$ & $\begin{array}{l}8.7 \\
14\end{array}$ & $11^{7.8}$ & $\begin{array}{l}20 \\
23\end{array}$ & $\begin{array}{l}19 \\
16\end{array}$ & $\begin{array}{l}32 \\
37\end{array}$ & $\begin{array}{l}6.3 \\
8.5\end{array}$ & $\begin{array}{l}13.1 \\
17.9\end{array}$ \\
\hline$P$ for heterogeneity & & & $P<0.001$ & $P<0.001$ & NS & NS & NS & NS & $P<0.05$ & $P<0.001$ \\
\hline \multicolumn{11}{|l|}{ Number of dairy cattle } \\
\hline $\begin{array}{l}\text { No cattle } \\
1-5 \text { cows } \\
6-8 \text { cows } \\
\text { Over } 9 \text { cows }\end{array}$ & $\begin{array}{l}1851 \\
1285 \\
1032 \\
1413\end{array}$ & $\begin{array}{r}1488 \\
1521 \\
969 \\
1288\end{array}$ & $\begin{array}{l}4.6 \\
3.1 \\
6.0 \\
6.6\end{array}$ & $\begin{array}{l}7.5 \\
12 \\
13 \\
16\end{array}$ & $\begin{array}{r}6.7 \\
8.7 \\
9.9 \\
11\end{array}$ & $\begin{array}{l}20 \\
22 \\
23 \\
24\end{array}$ & $\begin{array}{l}20 \\
15 \\
21 \\
17\end{array}$ & $\begin{array}{l}31 \\
32 \\
35 \\
45\end{array}$ & $\begin{array}{l}6.5 \\
5.4 \\
8.3 \\
8.4\end{array}$ & $\begin{array}{l}12.2 \\
15.9 \\
17.4 \\
19.9\end{array}$ \\
\hline$P$ for trend & & & $P=0.006$ & $P<0.001$ & $P=0.049$ & NS & NS & $P=0.016$ & $P<0.001$ & $\mathrm{P}<0.001$ \\
\hline \multicolumn{11}{|c|}{ Handling silage preservatives } \\
\hline $\begin{array}{l}\text { No } \\
\text { Yes }\end{array}$ & $\begin{array}{l}2772 \\
2809\end{array}$ & $\begin{array}{l}3319 \\
1947\end{array}$ & $\begin{array}{l}4.1 \\
5.9\end{array}$ & $\begin{array}{l}10 \\
14\end{array}$ & $\begin{array}{c}7.5 \\
10\end{array}$ & $\begin{array}{l}20 \\
25\end{array}$ & $\begin{array}{l}16 \\
20\end{array}$ & $\begin{array}{l}32 \\
41\end{array}$ & $\begin{array}{l}5.8 \\
8.3\end{array}$ & $\begin{array}{l}13.9 \\
19.8\end{array}$ \\
\hline$P$ for heterogeneity & & & $P=0.01$ & $P=0.001$ & NS & $P=0.032$ & NS & $P=0.028$ & $P<0.001$ & $P<0.001$ \\
\hline \multicolumn{11}{|c|}{ Daily handling of disinfectants } \\
\hline $\begin{array}{l}\text { No } \\
\text { Yes }\end{array}$ & $\overline{-}$ & $\begin{array}{l}2627 \\
2639\end{array}$ & $\dot{ }$ & 19.4 & $\dot{\cdot}$ & $\begin{array}{l}19 \\
24\end{array}$ & : & $\begin{array}{l}29 \\
41\end{array}$ & $\dot{.}$ & $\begin{array}{l}13.2 \\
19.0\end{array}$ \\
\hline$P$ for heterogeneity & & & . & $P=0.001$ & . & NS & . & $P=0.007$ & . & $P<0.001$ \\
\hline \multicolumn{11}{|l|}{ Machine servicing } \\
\hline $\begin{array}{l}\text { No } \\
\text { Yes }\end{array}$ & $\begin{array}{l}2670 \\
2911\end{array}$ & - & $\begin{array}{l}4.2 \\
5.9\end{array}$ & $\dot{.}$ & $\begin{array}{c}7.7 \\
10\end{array}$ & . & $\begin{array}{l}18 \\
19\end{array}$ & $\dot{.}$ & $\begin{array}{l}5.9 \\
8.1\end{array}$ & $\dot{\cdot}$ \\
\hline$P$ for heterogeneity & & & $P=0.014$ & . & NS & . & NS & . & $P=0.001$ & . \\
\hline
\end{tabular}

matoses showed a positive correlation with increasing number of dairy cows in the atopic dermatitis group. Fifty-one percent of the women with atopic dermatitis handled disinfectants daily, and $41 \%$ of them ( $42 \%$ in the atopic respiratory disease group) handled silage preservatives. Both types of activity increased the prevalence of hand dermatoses in the atopic dermatitis group, the latter also in the atopic respiratory disease group (table 1).

\section{Combined effect of constitutional and occupational risk factors on the occurrence of hand dermatoses}

The effects of risk factors on the prevalence of hand dermatoses were calculated in a linear regression model as risk ratios (RR). The results are listed in table 2. The risk of hand dermatosis was about threefold for the farmers with atopic dermatitis, and for the farmers with atopic respiratory disease there was almost twice the risk of the nonatopic group. For the female farmers, age uncier 35 years was also a risk factor for hand dermatoses. Significant risk ratios were also found for the risk of hand dermatoses among the male farmers who handled silage preservatives and among the female farmers who handled disinfectant detergents daily (table 2 ). When the linear regression analysis was made for the risk of hand dermatosis without other sites of dermatosis, atopic respiratory disease was the strongest risk factor for the men [RR $2.0,95 \%$ confidence interval (95\% CI) 1.4-2.8], followed by milking work (RR 1.7, 95\% CI 1.04-2.8). Atopic dermatitis (RR 1.8, 95\% CI $1.4-2.2$ ), atopic respiratory disease ( $R R$ 1.6, 95\% CI 1.3-1.9), and age under 35 years (RR 1.7, 95\% CI $1.3-2.2$ ) were the only significant risks for hand dermatosis alone among the women.

When both genders with all other covariates were together in the model, the female gender had a risk ratio of $2.5(95 \%$ CI $2.1-2.9)$ for all hand dermatoses and a risk ratio of $4.0(95 \%$ CI 3.1-5.3) for hand dermatosis without other sites of dermatosis. For all the farmers, milking work was a risk factor for hand dermatosis alone (RR $1.4,95 \%$ CI 1.04 1.8). Machine service work was also a risk factor of 
Table 2. Risk ratios (RR) and their $95 \%$ confidence intervals $(95 \% \mathrm{Cl})$ for the effects of the covariates on the one-year prevalence of hand dermatoses among Finnish farmers ( 5581 men and 5266 women). Analyses were separate for the genders. The models included the listed covariates. Deviance of the models: 634.0 (men) and 526.6 (women), degrees of freedom: 754 (men) and 471 (women).

\begin{tabular}{|c|c|c|c|c|}
\hline & \multicolumn{2}{|r|}{ Men } & \multicolumn{2}{|c|}{ Women } \\
\hline & RR & $95 \% \mathrm{Cl}$ & $\mathrm{RR}$ & $95 \% \mathrm{Cl}$ \\
\hline \multicolumn{5}{|l|}{ History } \\
\hline $\begin{array}{l}\text { No atopy } \\
\text { Respiratory atopy } \\
\text { Atopic dermatitis }\end{array}$ & $\begin{array}{l}1.00 \\
1.74 \\
3.56\end{array}$ & $\begin{array}{c}1.37-2.21 \\
2.84-4.46\end{array}$ & $\begin{array}{l}1.00 \\
1.82 \\
2.91\end{array}$ & $\begin{array}{l}1.57-2.11 \\
2.51-3.37\end{array}$ \\
\hline \multicolumn{5}{|l|}{ Age } \\
\hline $\begin{array}{l}55-64 \text { years } \\
45-54 \text { years } \\
35-44 \text { years } \\
18-34 \text { years }\end{array}$ & $\begin{array}{l}1.00 \\
0.94 \\
1.10 \\
0.97\end{array}$ & $\begin{array}{l}0.71-1.25 \\
0.82-1.49 \\
0.71-1.34\end{array}$ & $\begin{array}{l}1.00 \\
1.04 \\
1.07 \\
1.46\end{array}$ & $\begin{array}{l}0.87-1.25 \\
0.89-1.30 \\
1.19-1.79\end{array}$ \\
\hline \multicolumn{5}{|l|}{ Farm operation } \\
\hline $\begin{array}{l}\text { Plant cultivation or } \\
\text { not specified } \\
\text { Dairy cattle } \\
\text { Other animals }\end{array}$ & $\begin{array}{l}1.00 \\
0.80 \\
0.83\end{array}$ & $\begin{array}{l}0.56-1.13 \\
0.58-1.20\end{array}$ & $\begin{array}{l}1.00 \\
1.10 \\
1.23\end{array}$ & $\begin{array}{l}0.80-1.51 \\
0.93-1.61\end{array}$ \\
\hline \multicolumn{5}{|l|}{ Area of cultivation } \\
\hline $\begin{array}{l}0 \text { ha } \\
\leq 10 \text { ha } \\
11-20 \text { ha } \\
>20 \text { ha }\end{array}$ & $\begin{array}{l}1.00 \\
1.24 \\
1.18 \\
1.59\end{array}$ & $\begin{array}{c}0.65-2.36 \\
0.61-2.26 \\
0.83-3.05\end{array}$ & $\begin{array}{l}1.00 \\
1.15 \\
1.31 \\
1.11\end{array}$ & $\begin{array}{l}0.76-1.74 \\
0.86-1.99 \\
0.72-1.70\end{array}$ \\
\hline \multicolumn{5}{|l|}{ Milking } \\
\hline $\begin{array}{l}\text { No } \\
\text { Yes }\end{array}$ & $\begin{array}{l}1.00 \\
1.17\end{array}$ & $0.87-1.55$ & $\begin{array}{l}1.00 \\
1.21\end{array}$ & $0.93-1.58$ \\
\hline \multicolumn{5}{|l|}{ Handling disinfectants } \\
\hline $\begin{array}{l}\text { Not daily } \\
\text { Daily }\end{array}$ & $\begin{array}{l}1.00 \\
1.12\end{array}$ & $0.89-1.41$ & $\begin{array}{l}1.00 \\
1.18\end{array}$ & $1.02-1.38$ \\
\hline \multicolumn{5}{|l|}{$\begin{array}{l}\text { Handling silage } \\
\text { preservaties }\end{array}$} \\
\hline $\begin{array}{l}\text { No } \\
\text { Yes }\end{array}$ & $\begin{array}{l}1.00 \\
1.30\end{array}$ & $1.02-1.65$ & $\begin{array}{l}1.00 \\
1.12\end{array}$ & $0.98-1.28$ \\
\hline \multicolumn{5}{|l|}{ Machine servicing } \\
\hline $\begin{array}{l}\text { No } \\
\text { Yes }\end{array}$ & $\begin{array}{l}1.00 \\
1.15\end{array}$ & $0.93-1.41$ & $\dot{.}$ & . \\
\hline
\end{tabular}

all hand dermatoses (RR $1.2,95 \%$ CI $1.03-1.5$ ) and hand dermatosis alone (RR $1.4,95 \%$ CI $1.02-1.9$ ). Only 38 women did machine servicing, and 13 of them reported hand dermatosis.

\section{Discussion}

The reported lifetime incidence of atopic dermatitis was $10 \%$, that of respiratory atopy $23 \%$, and that of any atopic symptoms $29 \%$ in our study population. In other Scandinavian population studies $(4,5,8-$ 13), the lifetime incidences of atopic symptoms have been somewhat lower than or similar to those of this study. Our figures do not suggest that atopic farmers would have left the farming industry.

Our point prevalences for all reported dermatoses were comparable with the respective figures in four other Scandinavian postal surveys $(10,12,14,15)$. The point prevalence for skin diseases varied in these surveys between 16 and 24 (mean 18)\%. The point prevalence for skin diseases ranged between 16 and 31 (mean 21$) \%$ in clinical population studies $(8$, 16-18).
The point prevalences of hand eczema have varied between 8 and $14 \%$ in most clinical studies (12, $15,19-22)$, but also very different figures (1.7$83 \%$ ) have been found $(23-25)$. There are neither uniform criteria nor standards for the term eczema or dermatosis in clinical studies or in postal surveys; the result is a large variation in the prevalence figures. The point prevalence of self-reported hand dermatoses among the women of our study was somewhat higher $(11 \%)$ than that of clinical hand eczema among Lammintausta's hospital workers $(8 \%)$ (19). The one-year prevalence of self-reported hand eczema has varied from 5 to $9 \%$ among men and 11 to $15 \%$ among women in studies based on postal surveys of general populations $(26-28)$. The corresponding figures in the present study ( $7 \%$ for the men and $16 \%$ for the women) were similar to these prevalence figures.

The reliability and reproducibility of survey methods for epidemiologic studies of skin diseases have not been established in the literature. In addition, there are no standardized questionnaires for dermatologic research. The similarity in atopy prevalences in the present material with those of earlier studies allows us to assume that a questionnaire survey can detect atopic symptoms fairly relevantly. When the same questionnaire as in the present study was used three years later (in 1982) on the same population, similar prevalences of hand dermatoses were encountered, the point prevalence being $10.9 \%$ for the women and $4.9 \%$ for the men and the one-year prevalence being $16.8 \%$ for the women and $7.7 \%$ for the men (unpublished results). This finding suggests good reproducibility for the present method. Meding \& Swanbeck (27) found hand eczema in $89 \%$ of the persons who had stated that they had it ("considered themselves to have had hand eczema on some occasion during the previous 12 months") in the questionnaire survey. This finding suggests good reliability for the method, which was similar to ours. In the same Swedish study (5), the prevalences of hand dermatoses for persons with a history of no personal atopy and for persons with a history of skin atopy were strikingly similar to our figures. This fact also favors the concept that prevalences of dermatoses and atopy can be investigated with questionnaires.

About $50 \%$ of the farmers reporting hand dermatoses in the questionnaire also reported atopy. This figure is similar to that of the Swedish population study by Meding \& Swanbeck (5). The personal history of atopic dermatitis increased the risk for hand dermatosis about threefold in the present study (figure 2). The prevalence of hand eczema has been shown to be increased among people with a personal history of atopic dermatitis in many studies $(4,5$, 19, 29-31).

There is some controversy about the risk of hand eczema in respiratory atopics without the history of atopic dermatitis. The history of respiratory atopy almost doubled the risk for hand dermatosis among 
both the men and the women in our study (table 2). Atopic respiratory disease was the strongest risk factor for hand dermatosis among the male farmers without other sites of dermatosis. These findings agree with those reported by Nilsson (4), Meding \& Swanbeck (5), and Kristensen (31). Rystedt (3) reported that, in his study, the prevalence of hand eczema among people with a personal history of asthma equaled that of the nonatopic referents, being about 5\%. In Lammintausta \& Kalimo's study (11) of hospital personnel in wet work cumulative respiratory atopy alone without dry skin (atopic skin diathesis) did not increase the prevalence of hand eczema. In Rystedt's study there was also a strong correlation between dry and itchy skin and hand eczema when there was occupational exposure to moisture, detergents, or chemicals (3). The results were similar in a study by Fartasch et al (32), who found atopic skin diathesis but not respiratory atopy to be a significant risk factor for hand eczema in their logistic regression. These results are in accordance with those of a study by Werner (33), who found that only clinically dry skin of patients with atopic dermatitis had a lower water content than referents. Skin sensitivity (atopic skin diathesis) was not registered in the present study or in other studies where the history of respiratory atopy as such has been connected with higher prevalences of hand eczema (4, 5,31 ).

In Meding \& Swanbeck's (5) questionnaire study of an urban population the prevalence of hand dermatoses in the nonatopic group and the atopic dermatitis group were very similar to those of the present study, but there were significantly fewer cases of hand dermatoses in the atopic respiratory disease group of urban Swedes than in those of Finnish farmers (11.4 versus $15.5 \%$ ). This finding may be explained by the farmers' occupational exposure to respiratory allergens, which can also cause skin problems (eg, animal dander, flours). The prevalence of all dermatoses in the present study was also significantly higher for the atopic respiratory disease group than for the nonatopic group, among both the men and the women (figure 2).

On Finnish farms in 1979, women did most of the milking and were exposed to wet and dirty work, disinfectants, and allergens (animal dander, rubber, etc) more than men. Among female farmers, the risk for hand dermatoses was more than twofold, and for hand dermatoses without other sites of dermatosis the risk was fourfold that of the men's. The risk for hand dermatitis was higher for women under 35 years of age than for older women. There are also other studies that show higher hand eczema prevalences for women than men, and also higher prevalences for young women $(20,26,27)$. In addition to domestic work and other environmental exposures, constitutional factors of women may be involved.

Occupational risk factors were found especially in dairy farming (handling disinfectants, handling si- lage, and milking) and machine servicing, but they were weak compared with the constitutional ones. Among the men with hand dermatosis, but without other sites of dermatosis, milking was almost as strong a risk factor as atopy. When interactions with atopy and work were analyzed, atopy did not increase the effect of the work-related risk factors on the prevalence of hand dermatoses. The illogical finding that men with atopic dermatitis who milked regularly had less hand dermatoses than those who did not milk (table 1) was obviously due to the self-exclusion from milking work by those with hand dermatoses.

\section{Acknowledgments}

This study was financially supported by the Social Insurance Institute and the Farmers' Social Insurance Institute in Finland.

\section{References}

1. Mathias CGT, Morrison JH. Occupational skin diseases, United States. Arch Dermatol 1988;124:1519--24.

2. Vaaranen V, Vasama M, Toikkanen J, Jolanki R, Kauppinen T, editors. Ammattitaudit 1992 [Occupational diseases 1992]. Helsinki: Työterveyslaitos. Katsauksia $125,1993$.

3. Rystedt I. Hand eczema and long-term prognosis in atopic dermatitis [dissertation]. Acta Derm Venereol (Stockh) 1985:65 suppl 117.

4. Nilsson E. Individual and environmental risk factors for hand eczema in hospital workers [dissertation]. Acta Derm Venereol (Stockh) 1986:66 suppl 128;1 63.

5. Meding B, Swanbeck G. Predictive factors for hand eczema. Contact Dermatitis 1990;23:154-61.

6. Vohlonen I, Husman K, Kalimo E, Nuutinen J, Raitasalo R, Tupi K, et al. Viljelijöiden työ ja terveys 1979 [Farmers' work and health in 1979]. Helsinki: Kansaneläkelaitos, 1982. Kansaneläkelaitoksen julkaisuja A:17.

7. Wacholder S. Binomial regression in GLIM; estimating risk ratios and risk differences. Am J Epidemiol 1986;123:174-84.

8. Karvonen J, Sahi T, Kirjarinta M, Tiilikainen A. Skin diseases in a Finnish Lapp population. Oulu (Finland): Nordic Council for Arctic Medical Research, 1976: 38-43. Nordic Council for Arctic Research raport; no 16.

9. Peltonen L. Atopia ja nikkeliallergia [Atopy and nickel allergy] [dissertation]. Turku: University of Turku, Finland, 1979.

10. Hirvonen M-L, Hänninen K, Lehtinen M, Riala R, Riihimäki H. Muuraritutkimus [A bricklayer study]. Helsinki: Työeläkekassa, 1979. LEL työeläkekassan julkaisuja 3.

11. Lammintausta K, Kalimo K. Atopy and hand dermatitis in hospital wet work. Contact Dermatitis 1981;7:301-8.

12. Peltonen L, Wickström G, Selonen R. Occupational skin diseases in shipyard workers. Derm Beruf Umwelt 1983;31:87-9.

13. Schultz Larsen F, Holm NV, Henningsen K. Atopic dermatitis, a genetic-epidemiologic study in a population based twin sample. J Am Acad Dermatol 1986; 15(3): $487-93$.

14. Högberg $M$, Wahlberg JE. Health screening for occupational dermatoses in house painters. Contact Derma- 
titis $1980 ; 6: 100-6$.

15. Peltonen L, Vaahtoranta M, Wickström G. Ihottumat isossa elintarviketehtaassa [Dermatoses in a large food industrial plant]. Työterveyslaitoksen tutkimuksia 1984:2(3);177-82.

16. Wahlberg JE. Health-screening for occupational skin diseases in building workers. Berufsdermatosen 1969; 17:184-98.

17. Rea JN, Newhouse ML, Halil T. Skin diseases in Lambeth. Br J Prev Soc Med 1976;30:107-14.

18. Johnson M-LT, Roberts J. Skin conditions and related need for medical care among persons $1-74$ years, United States 1971 - 1974. Hyattsville (MD): National Center for Health Statistics, 1978. DHEW publication no (PHS) 9-1660. Data from the National Health Survey; series 11 ; no 212 .

19. Lammintausta K. Hand dermatitis in different hospital workers, who perform wet work. Dermatosen 1983; 31(1):14-9.

20. Singgih SIR, Lantinga H, Nater JP, Woest TE, Kruyt-Gaspersz JA. Occupational hand dermatoses in hospital cleaning personnel. Contact Dermatitis 1986; 14(4): $14-9$.

21. Larmi E, Reijula K, Hannuksela M, Pikkarainen S, Hassi J. Skin disorders and prick and patch test reactivity in Finnish reindeer herders. Derm Beruf Umwelt 1988;36:383-5.

22. de Boer EM, van Ketel WG, Bruynzeel DP. Dermatoses in metal workers (I): irritant contact dermatitis. Contact Dermatitis 1989;20:212 - 8 .

23. Agrup G. Hand eczema and other hand dermatoses in South Sweden [dissertation]. Acta Derm Venereol (Stockh) 1969;49 suppl 61:1-91..

24. Lantinga $H$, Nater JP, Coenraads PJ. Prevalence, incidence and course of eczema on the hands and fore- arms in a sample of the general population. Contact Dermatitis 1984;10:135-9.

25. Heise H, Kirschnick S, Dobreff U. Die Irritationsdermatose in der Landwirtschaft. Dermatol Monatschr 1983;169:625-30.

26. Kavli G, Førde OH. Hand dermatoses in Tromsø. Contact Dermatitis 1984;10:174-7.

27. Meding B, Swanbeck GS. Prevalence of hand ecze$\mathrm{ma}$ in an industrial city. Br J Dermatol 1987;116:62734

28. Smit HA, Burdorf A, Coenraads PJ. Prevalence of hand dermatitis in different occupations. Int J Epidemiol 1993;22(2):288-93.

29. Kuokkanen K, Grönroos P, Mäki H, Yrjänäinen R Sairaalahenkilökunnan käsi-ihottumat [Hand dermatoses in hospital personnel]. Suom Lääkäril 1982; $37(22): 1948-50$.

30. Rystedt I. Hand eczema in patients with history of atopic manifestations in childhood. Acta Derm venereol (Stockh) 1985;65:305-12.

31. Kristensen $\mathrm{O}$. A prospective study of the development of hand eczema in an automobile manufacturing industry. Contact Dermatitis 1992;26:341 - 5.

32. Fartasch M, Diepgen TL, Hornstein OP. Evaluation of endogenous factors and metal sensitivity in hand eczema. In: Ninth international symposium on contact dermatitis; May 17-19 1990 Stockholm Sweden: final program and book of abstracts. 1990:135.

33. Werner $Y$. The water content of the stratum corneum in patients with atopic dermatitis. Acta Derm Venereol (Stockh) 1986;66:281-4.

Received for publication: 29 November 1993 